\title{
Using Corporate Identity Artifacts to Shape the Practices of New Strategic Business Relationships
}

$\underline{\text { Authors }}$

Katy Mason, Lancaster U., k.j.mason@lancs.ac.uk

Claudia Simoes, Open U./ UK; Minho U./ Portugal, Claudia.Simoes@open.ac.uk 


\title{
Using Corporate Identity Artifacts to Shape the Practices of New Strategic Business Relationships
}

\begin{abstract}
Some forms of business relationship are of strategic importance to firms. The foundations of such relationships are often laid down in procurement processes. Knowing how to create a productive, trusting and committed relationship is challenging. Following the visual turn in organisational studies we explore the role of Corporate Identity (CI) in shaping new, strategically important relationships. Specifically, we show how CI artifacts are invoked in a complex procurement routine to generate an extraordinary outcome. Drawing on Clegg's notion of 'circuits of power' we show how social and material interactions iteratively shape the developmental stages of a relationship. CI artifacts are translated and embedded in boundary spanning objects by both organisations. Boundary objects act as obligatory passage points and represent transitions between different stages of a developing relationship. In the process CI artifacts are translated in to concrete situated practices that perform the relationship. Our findings contribute to the current understanding of how firms learn how to perform trust and commitment within an unfolding and uncertain relationship.
\end{abstract}

KEYWORDS: Corporate Identity Artifacts, New Business Relationships, Routines, Strategy as Practices, 


\section{Introduction}

Some business relationships are of strategic importance to firms, being central to their ability to adopt to and deliver what the market wants (Gulati, Nohria, \& Zaheer, 2000). Companies face the challenge of working out how to foster productive, trusting and committed relationships that create value for the suppliers, customers and other business network actors (Håkansson \& Snehota, 1995). In endeavouring to understand how strategically important relationships can be developed, scholars have studied relational contracting (MacNeil, 1980), working partnerships (Anderson \& Narus, 1990) and symbiotic marketing (Varadarajan \& Rajaratnam, 1986) and the study of the inter-firm routines that perform relationships (Dyer \& Singh, 1998; Jarzabkowski, Lê, \& Feldman, 2012; Kang, Mahoney, \& Tan, 2009). The continuity of exchanges and the emergence of routinized exchange practices stress the need for underlying corporate postures and behavioural consistency. The corporate identity (CI) literature highlights the role of visuals and materials in shaping business relationships development (Simões \& Mason, 2012) and contributes to the visual turn in management and organizational studies (Bell, Warren, \& Schroeder, 2014; Höllerer, Jancsary, Meyer, \& Vettori; Meyer, Höllerer, Jancsary, \& van Leeuwen, 2013).

CI concerns the company's being and uniqueness in the marketplace. In order to communicate their corporate identities companies use instruments, objects or artifacts to convey a desired image. Artifacts are the materials that mediate social relations and, as such, represent important components of distributed and complex sociomaterial configurations that form and perform contemporary business networks (c.f. Callon, 1980). Examples of CI artifacts are abundant in the visual identity/design literature incorporating organisational nomenclature, logos, company house styles, etc. (Carter, 1982; Olins, 1991). Other CI artifacts are values and mission statements (Simões, Dibb, \& Fisk, 2005). Attention on CI artifacts centres in consistently managing them in order to convey the desired image and instil positive behaviours towards the company amongst organisation's 
stakeholders. Such artifacts do not just reflect reality but intervene in it (Callon, 1998). Thus CI artifacts are recognized as having the power to act and shape practice.

Within supply networks, suppliers and buyers understand and interpret their trading partners' CI, which affects the business agreements reached and, ultimately, business performance (Robson, Leonidou, \& Katsikeas, 2002; Simões \& Mason, 2012). While the industrial marketing literature generates valuable insights into what makes relationships work, for example higher levels of commitment, co-operation and trust (Crespin-Mazet \& Ghauri, 2007; Morgan \& Hunt, 1994), much less is known about the materials that help this happen. We suggest that understanding how CI artifacts are used in the practice of forming a new business relationship could generate important insights into understanding how commitment, co-operation and trust might be developed.

This study explores how CI artifacts act as part of the sociomaterial configurations that form new business-to-business relationships. We draw on Clegg's (1989) 'circuits of power' framework to shows how social and material interactions shape intra-organisational practice, to explore the development of a new business-to-business relationship. Following a competitive tender process in a complex procurement setting, findings foreground forms of materials that shape the new business relationship: CI artifacts and boundary spanning objects, including invitation to tender - ITT, tender and workflow documents. We show how CI artifacts become linked to and embedded in the boundary spanning objects that frame how the unfolding business relationship is put into practice.

\section{Literature Review}

\section{Market Relationships and Supply Networks}

Business Relationship theory suggests that businesses benefit from long-term relationships customer and supplier relationships and that commitment and trust are central to this successful (Morgan \& Hunt, 1994; Urban, Sultan, \& Qualls, 2000; Zaheer, McEvily, \& Perrone, 1998). Similarly relevant are channel leadership, leadership style and channel power. Leadership style focuses on what the 
leader does and how it is done (Reve \& Stern, 1979; Stogdill \& Coons, 1957). Power is conventionally defined in the behavioural science literature as the ability to evoke a change in another's behaviour (Munson, Rosenblatt, \& Rosenblatt, 1999). Gaski and Nevin (1983) highlight the difference between channel power and channel leadership, commenting: "[n]ote, especially that power is defined as an ability, a potential, rather than actual alteration of behaviour".

Research into business networks has explored the dynamic nature of business relationships (Mishra \& Seshadri, 2000). For example, Eggert, Ulga and Schultz (2006) find that what becomes valuable in a business relationship changes over time (also see, Flint, Woodruff, \& Gardial, 2002; Ulaga, 2003). Similarly, the Market Studies literature shows that the material judgement devices used by managers to work out what is valuable, shape the emergent relationship practices (Azimont \& Araujo, 2010; Callon \& Muniesa, 2005). The power to influence and shape what the relationship becomes, shifts between the customer, supplier and the judgement devices that they use to evaluate their options and choices.

Clegg (1989) discusses the dynamic nature of power within organisations. His insights seem pertinent to inter-firm relationships. Clegg (1989) proposes three circuits of power (Figure 1) where social relations, artifacts and institutional systems or rules interact to allow power to shift over time. These observations are paralleled in the network literature. The first circuit recognises that episodes of interactions between individuals and artifacts within an organisation can cause shifts in power between actors. In a B2B context who or what is shaping the new relationship is also likely to change throughout the process. The network literature (Håkansson \& Snehota, 1995) refers to the episodic nature of inter-firm relationships within business networks. Clegg's (1989) second circuit draws on institutional theory to suggest that rules of practice are developed and made explicit to the actors in ways that facilitate (or restrict) social integration between individual actors or groups of actors. In the network literature Araujo (2007) discusses the institutional nature of the rules of engagement in inter-firm relationship development. An important issue raised by Clegg (1989) is the 
use of 'obligatory passage points'. The network literature is full of observations of such passage points in describing the development of new inter-firm relationships, exposing, for example, the challenges of developing contracts (Seshadri \& Mishra, 2004). When firms set out to develop interfirm relationships it seems likely that the rules they co-develop or impose on the relationship, together with the artifacts they develop and use to capture and convey these rules, are likely to influence the way the relationship develops and succeeds (Sluss \& Ashforth, 2008). These materials often emerge to bridge organisations or groups trying to work together and have been referred to in the organisation literature as boundary objects (Star \& Griesemer, 1989). Finally, the third circuit of power looks at how actors influence each other through domination/leadership and systems integration. The network literature recognises the role of systems integration through the exposure of inter-firm routines and practices that spread beyond the boundaries of the firm and into the wider network (Mason \& Leek, 2008).

In this way, markets can be understood as dynamic networks whereby the actions and intentions of actors within the network affect the development of business relationships (McLoughlin \& Horan, 2002). Developing an understanding of how firms capture and represent desired behaviours in artifacts that represent a translated, arbitrated view of a relationship, is likely to generate insights into how firms can cultivate successful B2B relationships and networks (Star \& Griesemer, 1989).

Figure 1: Circuits of Power Source: Clegg (1989:214)

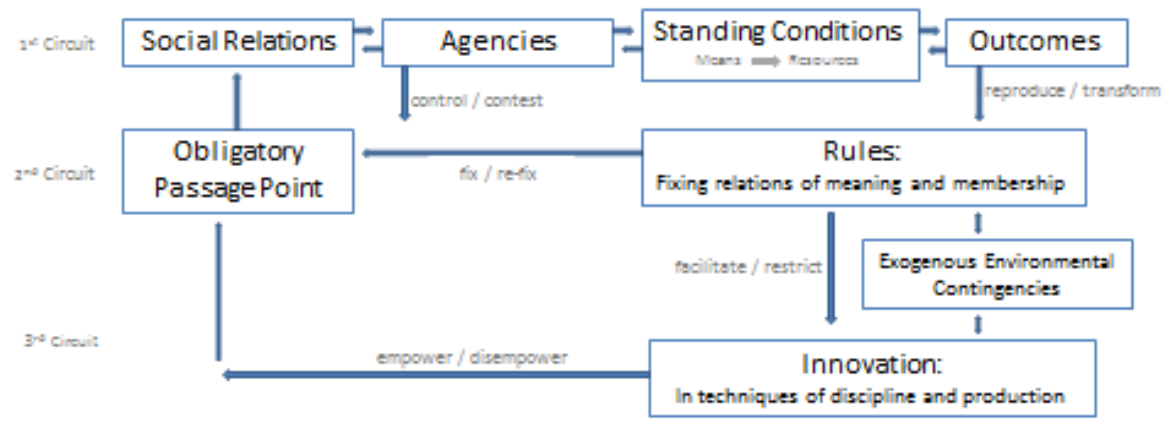




\section{Artifacts of Corporate Identity}

Early references to CI focus on symbolic and visual dimensions of identity, as addressed in graphic design/visual identity. Visual identity can be understood as the 'face' of the company. The underlying idea is to promote consistency across all possible forms of a company's physical identification in order to develop a strong corporate image (Topalian, 1984). Visual Identity is articulated in the forms of symbols, logos, house styles, visual systems, etc. (Gioia, Schultz, \& Corley, 2000; Melewar \& Saunders, 1999; Olins, 1991). All parts of a corporation that may be seen or heard are of relevance. There are numerous examples of CI becoming visually embedded in advertisements, uniforms, letterheads, business cards (Margulies, 1977; Pilditch, 1970). CI symbolism should be communicated to employees so that symbols are understood (Olins, 1991) and translated to the contexts of individuals work practices. This gives CI a plasticity and flexibility that allows the organisation to evolve (Gioia et al., 2000).

The concept of CI evolved to capture deeper features of identity beyond the visual aspects, exploring the uniqueness of the organisation. The following definitions capture this perspective: Identity "comprises the ways that a company aims to identify itself or position its product" (Kotler, 1997); CI “...is what helps an organization, or part of it, feel that it truly exists and that it is a coherent and unique being, with a history and a place of its own, different from others" (Kapeferer, 1996). The underlying idea is that each organization has its own individuality and uniqueness.

Although the domain of CI is not consensual, there is agreement on its multidimensionality and the exertion of management control over some features. Various CI mixes may be found in the literature. For example, $\mathrm{CI}$ is established to comprise symbols (visual identity and design aspects such as corporate name and house style), communication (all forms of internal and external corporate communications), and behaviour (how the corporation behaves involving aspects of corporate climate) (van-Riel \& Balmer, 1997). Allusions to CI also entail the reference to soul (e.g., values, culture), voice (e.g., communication) and mind (e.g., vision and philosophy) (Balmer \& Soenen, 
1997). According to Simões et al. (2005:153), pertaining to the internal management of CI is: “(1) the endorsement of consistent behaviour through the diffusion of a company's mission, values, and goals; (2) the expression and pursuit of brand and image consistency in the organization's symbols and forms of communication; and (3) the implementation, support, and maintenance of visual systems".

Managers have an interest in managing or manipulating symbols (e.g., rituals, physical settings) and other artifacts (e.g., mission and values), to convey an organisation's identity in a consistent way. It seems that a wide range of CI artifacts may be used to mediate contacts with stakeholders and to influence behaviours. For example, organisation's identity is core to understanding the employee's interpretations of issues; the formation of reactions; the types of emotions evoked. It also assists to understanding of how behaviours relate to the organisational context (Dutton \& Dukerich, 1991). Ashforth and Mael (1989:28) comment that, "it is tacitly understood by managers that a positive and distinctive organisational identity attracts the recognition, support, and loyalty of not only organisational members but other key constituents (e.g., stakeholders, customers, job seekers), and it is this search for a distinctive identity that induces organisations to focus so intensely on advertising, names and logos, jargon, leaders and mascots, and so forth". The articulation of behaviours and artifacts should be interactive and consistent in all its forms in order to transmit the desired identity.

\section{Corporate Identity Artifacts and Circuits of Power Shaping New Business Relationships}

We argue that CI artifacts help shape how new business relationships are conceptualized and performed. Managers turn to CI artifacts when working out the kind of relationship their organization will value and embed values in boundary objects (e.g., ITT, tender and workflow documents) that are

circulated amongst buyers/suppliers. In this way, mangers draw on abstract representations of desired corporate behaviour (signs, symbols, logos, values statements) and translate them into concrete, situated materials and practices (Callon, 1986). For example, when a buyer wishes to identify and develop a long-term relationship with a potential supplier, the buyer must communicate 
the intent to the potential supplier(s). This is usually done through an ITT. ITTs are widely available on the internet and many organisations have standard protocols for how they are presented and what to include. CI artifacts (e.g., company's logo and colours, mission and values, etc.) are often embedded in such documentation and, therefore, may act as a facilitator and judgement device when managers work to establish new B2B relationships.

We further suggest that CI artifacts are used by managers to create boundary objects by translating their conceptualisation and rules of how a corporation should behave into the specific situation or context. Ultimately they become a representation of how the new business relationship should work. As boundary objects circulate the embedded translations of CI, in turn, shape the conceptualisations and practices of the future supplier. Thus, customers, suppliers and CI artifacts have the power to shape the new relationship. We draw on Clegg's (1989) 'Circuits of Power' framework, and extend it to a new inter-firm relationship context. As our aim is to understand how new relationships unfold, the focus is on the first two circuits (Figure 2).

Figure 2. CI Artifacts and Circuits of Power in New Business Relationships

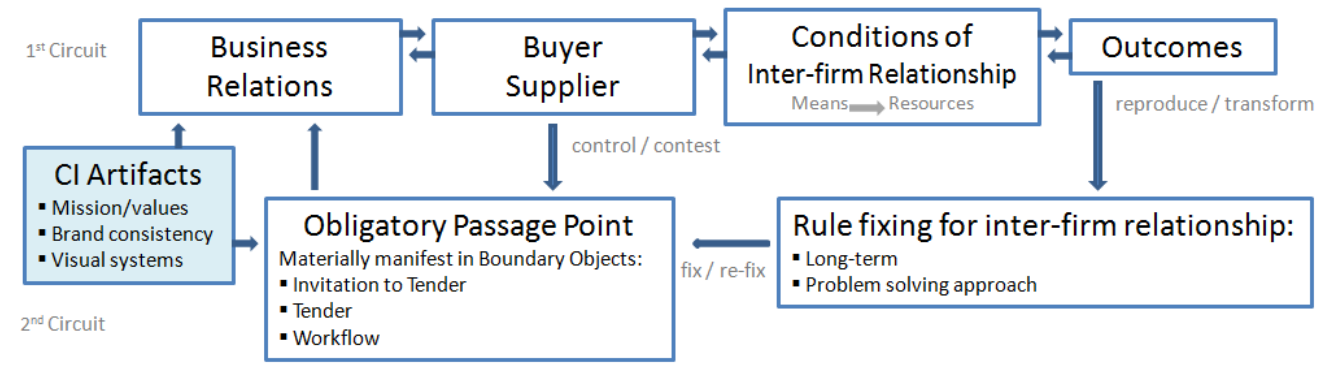

ITTs, tender and workflow materials can be seen to represent what Clegg refers to 'obligatory passage points'. For example, the buyer must develop the ITT at the early stages of a relationship. For the business network to develop, the supplier must then respond through the submission of a Tender Document to the buyer; each document portraying its own CI and reacting to the identity of the other. Thus, objects such as ITTs and Tender Documents may use CI artifacts to reflect and share 
organisational intent and actions. Boundary objects also represent mechanisms that allow actors to go through obligatory passage points during the development of the business network.

\section{Research Design}

In keeping with other studies of inter-firm dynamics (see for example, Eggert et al., 2006; Flint et al., 2002; Ulaga, 2003), we adopted a grounded approach to understand how new business relationships are shaped and developed (Strauss \& Corbin, 1998). Focusing on a single-case of complex procurement, we study CI artifacts and boundary spanning objects of four firms (one buyer and three potential suppliers), used in the initiation of a buyer-seller relationship (Flyvbjerg, 2007). We uncovered in-depth insights into the role of CI artifacts and boundary spanning objects in shaping a new relationship with a strategic nature. The context of a new relationship provided an opportunity to understand how actors translate and use artifacts when the actors are initially unknown to each other.

The study tracks the development of an emergent relationship through the pre-contract phase, analysing interactions and materials used to support interactions between buyer and potential suppliers throughout the tendering process. The buyer is a large, international, Europe-based, power systems firm (referred to as Navy Blue) and the three suppliers offer design engineering services (tooling, instrumentation and parts design). The suppliers are referred to as Red, Blue-Black and Blue-Orange, two of them are based in Europe and one in India. The sector into which Navy Blue sells its power systems is very tightly regulated; safety, quality and design accuracy, are always of major concern in procurement situations.

Data were collected over a twelve month period (a typical time-span in complex procurement) and included materials (artifacts), observations and thirty semi-structured interviews with those responsible for developing, presenting and interpreting the artifacts (Table 1). An interview guide helped explore inter-firm understanding and the perceptions each firm developed of the other, based on the 
events and objects. Key informants included interviewees from buyer and (potential) suppliers: the heads of each of the core functions (senior engineers) and the line-managers involved in the relationship.

The analysis focuses on how boundary objects are created and used in a new B2B relationship: (i) the ITT (prepared by the buyer and shared with the supplier); (ii) the Tender document (prepared by the supplier and shared with the buyer); (iii) the Work flow document (jointly prepared by the buyer and the successful supplier); (iv) other relevant materials (websites, PowerPoint deck). Materials were scrutinised for evidence of CI artifacts. How the CI artifacts are translated through the creation of the boundary objects is described and analysed.

Table 1. Key Informants, Interviews \& Materials*

\begin{tabular}{|c|c|c|c|c|c|}
\hline Company & $\begin{array}{l}\text { Interviewee } \\
\text { position }\end{array}$ & Name & $\begin{array}{c}0-6 \\
\text { months }\end{array}$ & $\begin{array}{c}6-12 \\
\text { months }\end{array}$ & Materials \\
\hline \multirow{4}{*}{ Buyer (Navy Blue) } & Senior Buyer & Martin & 3 & 3 & \multirow{4}{*}{$\begin{array}{l}\mathrm{Cl} \text { artifacts (logos, value/mission } \\
\text { statements, company house style); } \\
\text { Powerpoint deck; ITT; Website; } \\
\text { Workflow documents }\end{array}$} \\
\hline & Director & Will & 2 & 2 & \\
\hline & Senior Manager & George & 3 & 3 & \\
\hline & Director & Geoff & 2 & 2 & \\
\hline \multirow[t]{2}{*}{ Supplier (Blue-Orange) } & Director & Sam & 2 & 2 & \multirow{2}{*}{$\begin{array}{l}\text { Cl artifacts; Powerpoint deck; } \\
\text { Tender; Website } \\
\text { Workflow documents }\end{array}$} \\
\hline & Senior Manager & Jack & 2 & 2 & \\
\hline Supplier (Red) & Senior Manager & John & 1 & - & $\begin{array}{l}\text { Cl artifacts; Powerpoint deck; } \\
\text { Tender; Website }\end{array}$ \\
\hline Supplier (Blue-Black) & Senior Manager & Jim & 1 & - & $\begin{array}{l}\mathrm{Cl} \text { artifacts; Powerpoint deck; } \\
\text { Tender; Website }\end{array}$ \\
\hline
\end{tabular}

*Firms and employees have been renamed to protect their identity.

In order to protect the anonymity of the actors we present stylized facts, i.e., present simplified empirical findings (Kaldor, 1961). These are widely adopted in the social sciences and more typically in economics (see for example, Demirgüç-Kunt \& Levine, 1996). Stylized facts present the essence of the CI artifacts without revealing the specific identity of the organisation.

\section{Findings}

\section{$1^{\text {st }}$ Circuit: Episodes of Interaction}

The first circuit (Figure 2) represents the initiation of the business relationship. Early interaction episodes allow the actors to understand the means and resources that will become available if a business relationship 
is developed. Once the buyer decided to buy-in design services, they began to identify and approach potential suppliers. As soon as the buyer starts to interact with a supplier, the business relationship begins (c.f. Ford, 2003). For some suppliers the relationship was short and stopped directly after the initial enquiry. Martin (Senior Buyer) explained: "We talked to them on the phone first. Of course we knew some of them [the suppliers] from other business ... others [suppliers], we just wanted to checkout,... [pause] even though we knew they were long shots.... We didn't contact them again."

Martin and his colleague also looked at suppliers' websites. They deliberately explored different aspects of the corporate identities of potential suppliers. This enabled the Martin and his team to develop some understanding of the different kinds of organisations that offered design services. During this process, Martin's team encountered multiple CI artifacts (e.g., logos, mission and value statements) (Simões et al., 2005). All websites had positioning statements explaining the work their company did and often describing themselves as, "innovative", "world leaders in..." and "creating value". Sites often provided value statements such as: "We create value by successfully understanding your requirements, to create effective, engineering and business solutions." and "The [XXX] teams are trained to listen, acquire and develop skills, be able to adapt to the inherent challenges of innovation, risk control, complexity, and to convert our customers' goals into the results of our joint projects."

Martin described the different looks of the websites: "... most of them were engineeringy... photos of kit, CAD drawing... lots of pictures of people looking at computer screens... Red and blue were the dominant colours really, though I did come across a green and grey one."

The points of interest for Martin and his colleagues were the 'cases studies' that described past projects, customer relationships and the values of the supplier. During this search, Martin and his team also looked at their own corporation's website. Martin commented: "It was so striking. On our page we have this phrase 'relied on to deliver quality' - I ended up using in my pitch to suppliers when I was trying to explain what we needed from them..... But when I first saw it, it was sooooo striking, it made me think ...." 
Martin identified three suppliers that seemed 'more interesting'. Until now, business relationships had been mediated through website materials and phone call information. In the first circuit of power Martin and his team draw on CI artifacts of potential suppliers by accessing websites and referring to how these suppliers present themselves. This shapes the buying team's conceptualisation of the types of services and working relationships that the market can offer, frames the buyer develops (Callon, 1998) and what Clegg (1989) calls the 'conditions' of the inter-firm relationship. The Outcome of the first circuit (Figure 2), is that the buyer has a rudimentary understanding of the services that might be bought. Martin discusses this with the team that will use the services and together they develop a framework for an imagined relationship that could conceivably successfully deliver the design services.

\section{$2^{\text {nd }}$ Circuit: Institutionalised Practices}

Martin met with senior engineers and business development managers within Navy Blue to draft the ITT. The drafting of the document was set up in a workshop-type session. Participants met away from their normal workplace. This constitutes one of the first acts of fixing the rules of the inter-firm relationship and moves the tendering process into the second circuit of power (Figure 2). The ITT is an obligatory passage point (Clegg, 1989) and must be prepared before the relationship can be further developed. Rule fixing and the preparation of an ITT are institutionalised practices. However, how these practices are performed, and what shapes their performance in this specific context is of interest, as this is likely to affect whether trust and commitment begin to emerge in the relationship (Crespin-Mazet \& Ghauri, 2007).

At the workshop where the ITT was drafted, discussion focused on the challenges of specifying the type of work that was to be "bought in"; work hours, specific design tasks and skill levels were unclear. The discussion turned to how the ITT might represent the "spirit" of the relationship as a way of compensating for the lack of technical specification. Based on the information collected from the potential suppliers' web pages, the participants listed the desired characteristics of suppliers: 'reliable', 'trustworthy', 'able to solve problems as we hit them', 'understand how we work', 'have had experience of working closely with a big 
customer like us'. The work to draft the ITT unfolds in the workshop (Table 2). Of note is the way Martin's team translate abstract $\mathrm{CI}$ artifacts into the situated practices of their particular group and represent them in the ITT document.

Table 2: Extract from the Workshop to Draft the ITT

\begin{tabular}{|c|c|}
\hline Actors & Quotes \\
\hline Martin: & "what's different or difficult about what we're trying to do?" \\
\hline Eng\#1: & $\begin{array}{l}\text { "we don't know what our guys are going to do yet and what they [the supplier] will do? We don't know how we'll work } \\
\text { together, so it needs to be folks that can tune-in to our way of working" }\end{array}$ \\
\hline Eng\#2 & "we have to trust them, they've got to be reliable especially when we get snags" \\
\hline Manger\#1 & "what have we got here that show they [suppliers] know how to deal with problems, and can use their own initiative?" \\
\hline Martin & "there are cases on that one" [points to printed web pages being examined by Eng\#1] of the.." \\
\hline Development & "and were talking three years minimum here -it's got to be a more established thing-we're not talking bums on seats \\
\hline Manager\#3 & for a few hours. We're talking serious engagement - 'cause they'll have to learn our systems, protocols." \\
\hline Eng\#1 & "it says here they their innovative [laughter from the room]" Eng\#1 points to web printout. \\
\hline Eng\#2 & "how innovative do you reckon they'll be when the bloody tools don't fit!" [more laughter] \\
\hline Manager\#2 & "but we do need them to solve problems right? On an ongoing basis" \\
\hline Eng\#3 & "that's the nature of the work..." \\
\hline Manager \#1 & $\begin{array}{l}\text { "it says here [refereeing to supplier's web page], 'Building a relationship with [XXX] that goes back over [X] years, } \\
\text { [Supplier] was selected as a global partner capable of monitoring development programs for new, high- } \\
\text { performance materials and manage part of the qualification of these materials and the relevant implementation } \\
\text { processes...'...blar, blar, blar, and they 'improved and standardized the operating processes'... }\end{array}$ \\
\hline Martin & "OK, so what would that mean for us - with what you're trying to do?" \\
\hline
\end{tabular}

The ITT embeds CI artifacts by translating them into the specific context of an imagined relationship, including values, time scales and approaches to the relationship. Figure 3 illustrates the chain of translation from the abstract CI artifacts (in the form of colours, logos, value statements) into the concrete, situated rules of the relationship (long-term relationship, problem solving, shared information systems, etc.) that constitute the ITT.

By focusing on the need for the firms to work closely together and for the supplier to understand and adopt the buyer's 'ways of working', the buyer is trying to identify and share with potential suppliers the likely rules of the inter-firm relationship. The ITT acts as a boundary object that spans and connects the buyer with suppliers and represents what the buyer is as an organisation, its aim, values and intentions, as well as what it is hoping to achieve from the relationship. Martin (with the ITT in front of him): “... and you can see, the usual layout... it's quite basic at this stage. But it's clear, and essentially, you get what we are trying to do here; shared learning, innovative process solutions... trust." 
Figure 3: Chain of Translation from CI Artifact to ITT

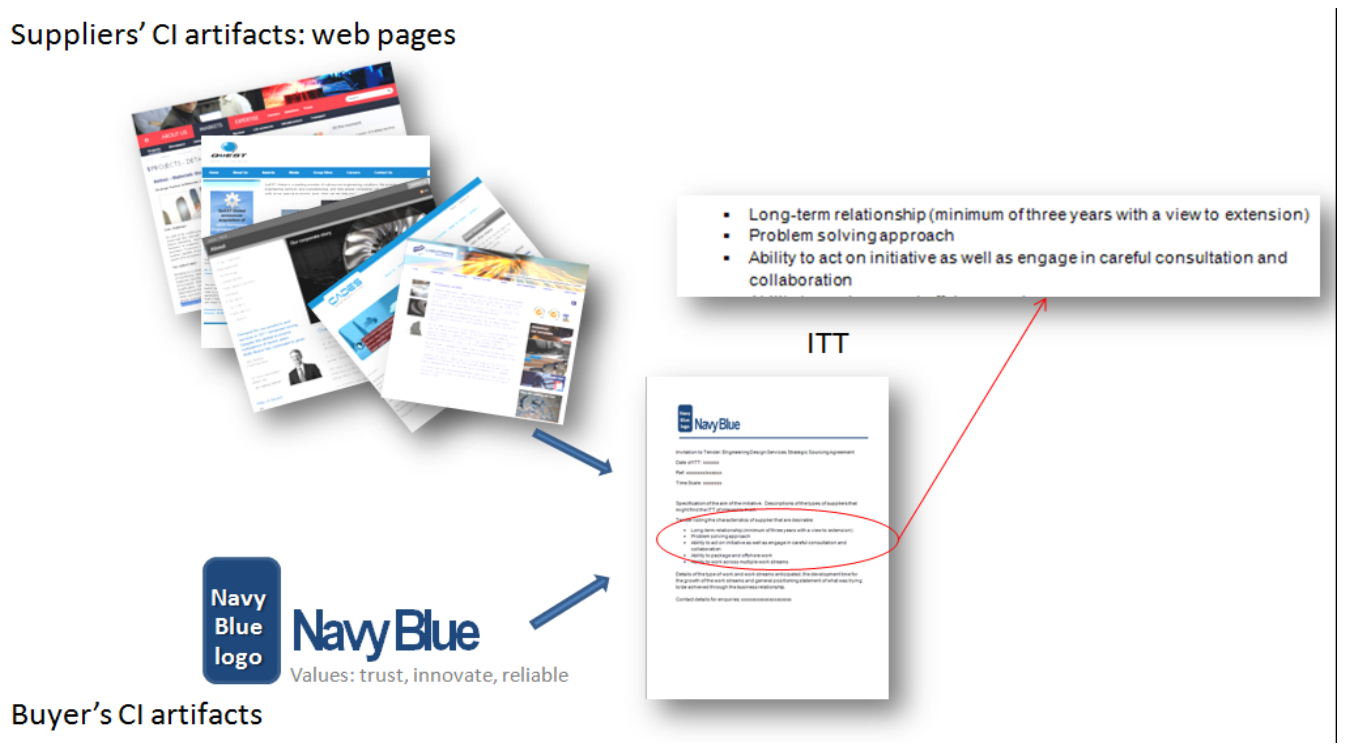

As Martin describes what he is trying to represent in the ITT he shifts from the concrete to the abstract: pointing at the concrete description of the need to integrate systems as he says 'shared learning' and to the description of how the supplier might package and bundle work, while saying 'innovative process solutions'. The ITT is capturing and presenting the CI of the buyer to the supplier. The visual system, brand and values, as fundamental aspects of CI (Simões et al., 2005), become translated and embedded in the ITT, an obligatory passage point that drives the business relationship. Sometimes CI artifacts travel unchanged (the logo, the corporate colours and the company name appear on the ITT), and others, as with the corporate values of 'trust' and 'innovation', they are translated into the specific context. The ITT is not just an obligatory passage point, but a boundary object that connects the buyer with the supplier. The ITT is circulated to suppliers and so brings the process back to the first circuit of power.

\section{Return to the $1^{\text {st }}$ Circuit}

The ITT is sent to potential suppliers. Martin and his team had received several enquiries, and decide to bring the suppliers together in a workshop so that they could "see the competition and up their game." Martin prepared a presentation where he talked to the suppliers about "the spirit of the relationship" that he had worked to capture in the ITT. The presented slide deck (Figure 4) followed the corporate visual system 
using a standard slide background, company logo and name. The slide deck attempted to translate the company's values into this specific working relationship. Martin had slides titled, 'Trust', 'Innovation' and 'Reliability'. The last slide read, 'our reputation in your hands'. Each supplier presented an outline of their market offering (no costing/prices were detailed). Three of the slide decks are presented in Figure 4, portraying the essence of the approach taken. The suppliers slide decks are very different from each other but each incorporates its own CI artifacts. Red's slides uses the company's name/logo. Blue-Black and Blue-Orange use their own logo and Navy Blue's logo.

Figure 4: Continuing the Chain of Translation: Supplier Meeting \& Tender

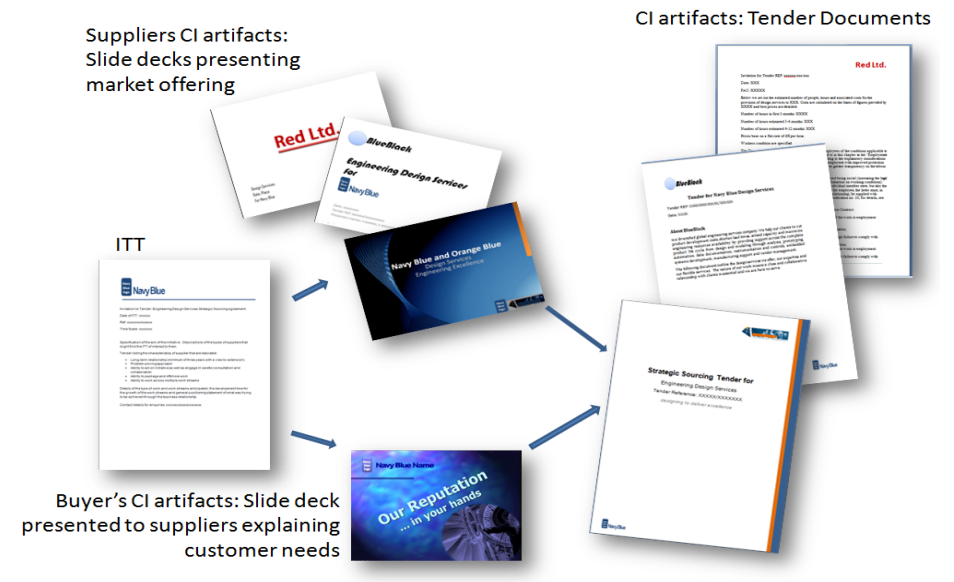

Blue-Orange goes further than just representing the two corporate visuals by re-presenting specific sections of the ITT. At the top of each slide was a title, followed by a quote taken from the ITT, followed by BlueOrange's response to that specific issue. The connections made on each slide showed the same connections that Navy Blue had been making when preparing the ITT. For example, on Blue-Orange's slide titled 'Innovation' (a Navy Blue value), Blue-Orange re-presented Navy Blues translation of how they wanted the supplier to innovate the way work would be packaged, followed by suggestions of how Blue-Orange might do this. Sam (Director, Blue-Orange) explained that the ITT together with informal communications with the buyer, led them to make a serious bid for the business, "We saw the ITT, we knew we were in with a chance....the conversations we'd been having with [the buyer] ...had had some impact ... the wording, the language....". Sam's observation suggests the tone of the relationship emerging between Navy Blue and 
Blue-Orange and recognises the chain of translation between the CI artifacts -'the wording, the language' from the values of the two companies.

The outcome of the supplier-buyer presentations was that Navy Blue became particularly interested in BlueOrange, yet other firms decided to submit a Tender. By deciding to Tender actors re-enter the second circuit of power and the work to develop the tender document entails further rule fixing for the relationship.

Return to the $2^{\text {nd }}$ Circuit

The buyer awards the contract based on the Tender. The Tender document is the second 'Obligatory passage point' and again acts as a boundary object between buyer and supplier. Figure 4 presents the Tender documents of three suppliers. Red's tender document is short (3 pages) and focuses on the cost and pricing of services. Red uses its logo and Times Roman type face, making no connection or reference to Navy Blue's CI's artifacts. Blue Black's Tender is also quite short (7 pages) and includes both their own logo and Navy Blue's logo (bottom right) on the front page. The tender document begins with a focus on the type of company Blue-Black is - a positioning statement that encompasses the values of the firm. BlueOrange presents a document with a clearly distinguishable and separate front cover. Both their own and Navy Blue's logo are displayed. Both firms have a similar dark blue as part of their logo and this is used to combine the two firms with a vertical orange and blue stripe down the page. Blue-Orange also adopts Navy Blue's type face and adapts a value statement from Navy Blue, to join the two firms through the tender document: from 'relied on to deliver quality' to 'designing to deliver quality. Sam was concerned to show the buyer that Blue-Orange and Navy Blue had shared values,

"We knew we needed to communicate this [shared values] in our response to the ITT....We decided to bring in some communication specialists. A PR [public relations] firm we'd used before... They looked at the ITT and they looked at our material, they talked to us and then they were like a mirror. They [the PR firm] used their [the buyer's] words to head up sections; 'the service', 'the 
relationship', 'problem solving', 'shared learning',... it was amazing. They seemed to get the essence of our company and [the buyer's firm] in the layout of the document. It looked amazing."

The supplier seemed very aware of the role of visual systems and their use in conveying what were perceived as shared values. The inference was that aspects of the supplier's CI that echoed or mirrored those of the buyer would positively influence the development of the relationship. The supplier's claim of wishing to align the identities and specifically the values of the buyer's organisation with the supplier's, did not appear to be superficial. The data suggest that this was of genuine concern to 'choosing the right business partner'. It seems likely that through the practice of mirroring and representing the buyer's needs, the supplier was able to perform aspects of trust and commitment with the buyer by showing they had listened to the buyer. The supplier conveyed understanding of what the buyer considered valuable in the emerging relationship. This finding seems particularly pertinent to the emergent value creation literature that has begun to recognise that both social and economic value creation are important in $\mathrm{B} 2 \mathrm{~B}$ relationships (Flint et al., 2002; Ulaga, 2003) and that what is perceived as valuable is likely to change as a relationship develops (Eggert et al., 2006). Blue-Orange made use of CI artifacts to both understand and communicate their understanding of what was valuable to the supplier.

The transparency that Blue-Orange gave to the translation process distinguished their slide deck and Tender documents from the materials of other suppliers. The outcome was that Sam's firm (Blue-Orange) was successful in their Tender. Martin (Senior Buyer) explained how the Tender documents compared: "In the end, there was only really one firm that got it, that understood what we were looking for. It stood out a mile in the Tender." The contract was signed and the next stage of inter-firm relationship brought the two circuits of power to operate in tandem.

\section{$1^{\text {st }}$ and $2^{\text {nd }}$ Circuits in Tandem}

After the contract award, the buyer focuses on the relationship with the single supplier Blue-Orange. To implement the supply agreement a workflow document was co-produced by Navy Blue and Blue-Orange 
managers. The workflow document is the third boundary object that incorporates CI artifacts. This document detailed practices that moves work across organisational boundaries (Figure 5). While the workflow document incorporated both companies' logos and was produced in the house style of the buyer, the visual aspects of the companies identities is less prominent than it was in the ITT and Tender documents. As Jack (Supplier) explained: "I worked with George, so we had mapped out every stage of the work flow. We knew who should be doing what, and if there was a problem, how we could escalate it." The workflow document emerged over time through several iterations. The buyer and supplier invested in understanding where the resources, the means to access the resources, and the control of those resources, within each firm. This was a complex task as the buy-in involved hundreds of engineers working in different geographic sites, across three organisational boundaries (as some work was to be subcontracted).

Figure 5. Workflow Document Detailing Working Practices: Who What How

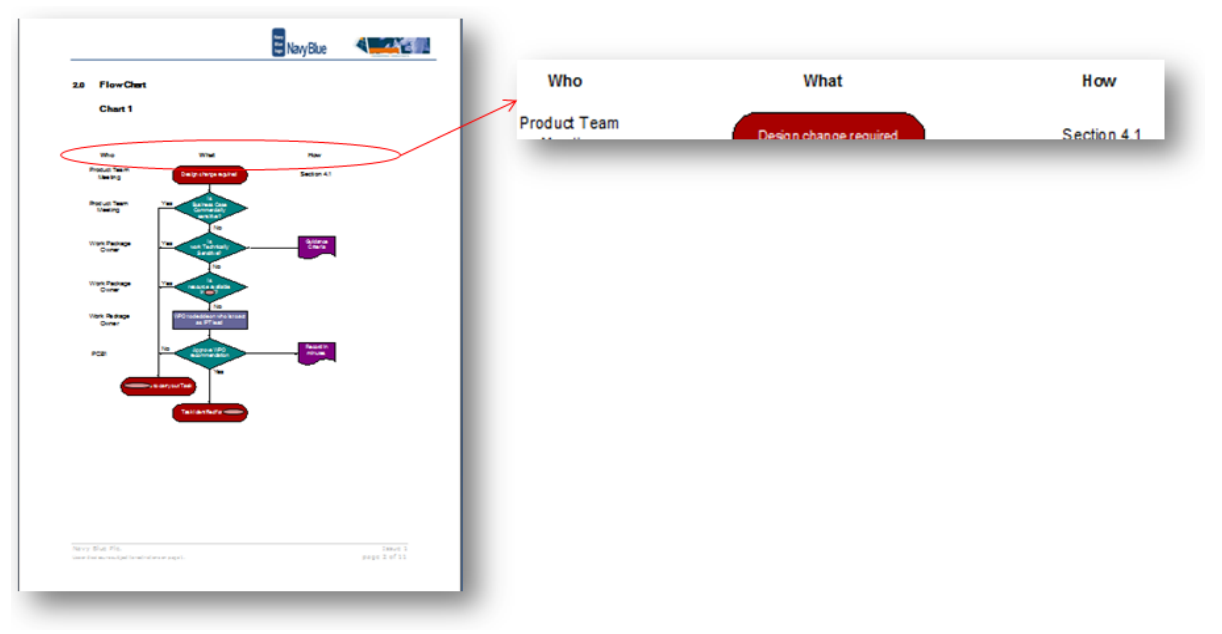

Throughout time, the outcomes and sometimes misunderstanding of the conditions created a 'problem' that required attention from actors. Solutions often lead to the re-fixing of rules $\left(2^{\text {nd }}\right.$ circuit) and routine returns to this Obligatory Passage Point. Despite this, the actors did their work in the 'spirit' of the agreement. The 'problem solving approach', represented in the original ITT could be seen in the working practices. While the textual aspects of CI are not prominent at this point, it is easy to recognise who is involved in the relationship from the logos and how the workflow represents the values of the actors. Other CI artifacts 
have materially disappeared. Yet, amended workflow diagrams have helped to and strengthen the relationship despite hiccups and changes in the conditions. CI became embodied in the everyday working practices of those performing the relationship (c.f. Dutton \& Dukerich, 1991). This is an extra-ordinary outcome for Navy Blue. The majority of their supplier relationships are contracted on quality and price and do not draw on CI artifacts in the framing of ITTs.

\section{Conclusions}

This research adds to a deeper understanding of the materials and practices of new B2B relationships. In particular, the study contributes to our understanding of the power of visual systems in framing new relationship by showing how CI artifacts are used to shape and frame buyer/supplier relationships. Findings highlight the role of 'imageries-of-practice' in fixing rules and values in a new business relationship (Höllerer et al.) but also show the plastic nature of abstract visual systems as translated in to practical projects of production (Gioia et al., 2000). CI artifacts help managers frame action by offering abstract ideologies or principles (trust and reliability, for example) that can be translated into the situated practices of an emergent relationship. Such translations create a common ground and frame how the relationship might work: mapping what matters to the relationship and what does not (Callon, 1998). Drawing on the notion of Clegg's 'circuits of power' findings present the framing of a relationship as a continuous, iterative process that is shaped by CI artifacts from both buyers and suppliers, and buyer-supplier interactions. Thus, CI artifacts are shown to have the power to affect how the practices of a new business relationship unfold.

The second contribution relates to how CI artifacts become important components of boundary spanning objects. Similar to other studies on the sales and tendering process (Geiger \& Finch; Koskinen \& Mäkinen, 2009), this research shows the role of boundary objects in the development of buyer-supplier relationship. Additionally, the study shows how CI artifacts are used through a translation process, become embedded in boundary objects and shape the unfolding practices of those trying to make the relationship work. This finding extends research in relationship atmosphere and 
supply chain culture (Gadde, 2004; Hult, Ketchen, \& Arrfelt, 2007) and provides evidence of how specific relationship development activities create trust and commitment (Crespin-Mazet \& Ghauri, 2007).

The insight into how CI artifacts become embedded in boundary objects also has implications for understanding the valuation practices of managers trying to work out who to work with and how, when developing their business networks. Thus, the way CI artifacts are used as evaluative judgment devices might offer a way forward to look at the valuation practices of both the economic and social aspects of an emergent relationship (Eggert et al., 2006). CI artifacts may make an important contribution to the emergence of orders of worth (i.e., what is valued in a relationship, by whom and why) as we understand more about what CI artifacts do and how they circulate (Azimont \& Araujo, 2010; Clegg, 1989).

The third contribution is to the CI literature. While Simões et al. (2005) contribute to our understanding of the tools and materials of CI management, our findings show how managers and frontline workers put CI artifacts to work. These insights emerge by following the chain of translation: (a) from ideologies (trust, innovation); (b) to their physical manifestation as CI artifacts (logos, visual systems and value statements); (c) to translation into a specific context (seen in the ITT and tender documents); (d) and, finally, to their embodied performance. These findings generate insights into the performative power of CI artifacts, as well as how they become embodied through their translation into situated practice, acting as the co-ordinating visual system of a procurement routine (Jarzabkowski et al., 2012).

This research extends Cleggs (1989) concept of circuits of power to an inter-firm context. The framework enables us to see how power shifts between buyer and supplier as the relationship develops and different capabilities and skills sets, become foregrounded. Findings demonstrate how materials and practices shape the next innovative steps in an emergent relationship. This has two 
important implications for managers. First, it suggests how managers might make use of CI artifacts in the formation and development of a business relationship. CI artifacts can help buyers judge the market potential by analysing suppliers' representations of their offers. By embedding and translating CI artifacts into boundary objects, managers can draw on CI artifacts to help them frame the outcomes and rules for the relationship. Second, the iterative way that the first and second circuits develop, shows the shift in power as the relationship evolves. This enables buyer and suppliers to see how identities could or should become translated and embedded in the documents reflecting the context and the moment of the relationship. By making the use of both buyer and suppliers' CI artifacts as part of the institutionalised practices of new relationship development processes, managers will be able to better organise and develop their procurement activities.

This study presents some limitations pertaining of a single case design. Due to the qualitative nature of the investigation, the sample size was limited. Yet the scope of the research demanded an in-depth analysis of the artifacts and the actions. Future research could follow the nature and usage of artifacts throughout the development of the relationship, beyond the tendering process.

\section{References}

Anderson, J. C., \& Narus, J. A. 1990. A Model Of Distributor Firm And Manufacturer Firm Working P. Journal of Marketing, 54(1): 42.

Araujo, L. 2007. Markets, market-making and marketing. Marketing Theory, 7(3): 221-226.

Ashforth, B. E., \& Mael, F. 1989. Social Identity Theory and the Organization. Academy of Management Review, 14(1): 20-39.

Azimont, F., \& Araujo, L. 2010. Governing firms, shaping markets: The role of calculative devices. In L. Araujo, J. Finch, \& H. Kjellberg (Eds.), Reconnecting Marketing to Markets: 94-116. Oxford: Oxford University Press.

Balmer, J., \& Soenen, G. 1997. Operationalising the Concept of Corporate Identity: Articulating the Corporate Identity Mix and the Corporate Identity Marketing Mix. Working Paper Series International Centre for Corporate Identity Studies, University of Strathclyde.

Bell, E., Warren, S., \& Schroeder, J. 2014. The Routledge companion to visual organization. New York, NY: Routledge.

Callon, M. 1980. Struggles and negotiation to define what is problematic and what is not: the sociology of translation. In K. K. Cetina, R. Krohn, \& R. Whitley (Eds.), The Social Process of Scientific Investigation: 197-219. Boston: Reidel.

Callon, M. 1986. Some Elements of a Sociology of Translation: domestication of the Scallops and the Fisherment of St-Brieuc Bay. London: Routledge \& Kegan Paul. 
Callon, M. (Ed.). 1998. 'Introduction: The Embeddedness of Economic Markets in Economics' in The Laws of the Markets. Oxford: Basil Blackwell.

Callon, M., \& Muniesa, F. 2005. Peripheral Vision: Economic Markets as Calculative Collective Devices. Organisation Studies, 26(8): 1229-1250.

Carter, D. 1982. Designing Corporate Identity Programs for Small Corporations. New York: Art Direction Book Company.

Clegg, S. 1989. Frameworks of Power. London: Sage.

Crespin-Mazet, F., \& Ghauri, P. 2007. Co-development as a marketing strategy in the construction industry. Industrial Marketing Management, 36(2): 158-172.

Demirgüç-Kunt, A., \& Levine, R. 1996. Stock Market Development and Financial Intermediaries: Stylized Facts. The World Bank Economic Review, 10(2): 291-321.

Dutton, J. E., \& Dukerich, J. M. 1991. Keeping an Eye on the Mirror: Image and Identity in Organizational Adaptation. The Academy of Management Journal, 34(3): 517-554.

Dyer, J. H., \& Singh, H. 1998. The relational view: Cooperative strategy and sources of interorganizational competitive advantage. Academy of Management. The Academy of Management Review, 23(4): 660.

Eggert, A., Ulaga, W., \& Schultz, F. 2006. Value creation in the relationship life cycle: A quasilongitudinal analysis. Industrial Marketing Management, 35(1): 20-27.

Flint, D. J., Woodruff, R. B., \& Gardial, S. F. 2002. Exploring the Phenomenon of Customers' Desired Value Change in a Business-to-Business Context. Journal of Marketing, 66(4): 102117.

Flyvbjerg, B. 2007. Five misunderstandings about case-study research. London and Thousand Oaks, C.A.: Sage.

Ford, D. 2003. Managing Business Relationships. Chichester: Wiley.

Gadde, L.-E. 2004. Activity Coordination and Resource Combining in Distribution Networks Implications for Relationship Involvement and the Relationship Atmosphere. Journal of Marketing Management, 20(1-2): 157-184.

Geiger, S., \& Finch, J. Industrial sales people as market actors. Industrial Marketing Management, 38(6): 608-617.

Gioia, D. A., Schultz, M., \& Corley, K. G. 2000. Organizational identity, image, and adaptive instability. Academy of management Review, 25(1): 63-81.

Gulati, R., Nohria, N., \& Zaheer, A. 2000. Guest editors' introduction to the special issue: strategic networks, Strategic Management Journal, 21 ed.: 191-201.

Håkansson, H., \& Snehota, I. 1995. Analysing Business Relationships. London: Routledge.

Höllerer, M. A., Jancsary, D., Meyer, R. E., \& Vettori, O. Imageries of Corporate Social Responsibility: Visual Recontextualization and Field-Level Meaning, Institutional Logics in Action, Part B: 139-174.

Hult, G. T. M., Ketchen, D. J., \& Arrfelt, M. 2007. Strategic supply chain management: Improving performance through a culture of competitiveness and knowledge development. Strategic Management Journal, 28(10): 1035-1052.

Jarzabkowski, P. A., Lê, J. K., \& Feldman, M. S. 2012. Toward a Theory of Coordinating: Creating Coordinating Mechanisms in Practice. Organization Science, 23(4): 907-927.

Kaldor, N. (Ed.). 1961. Capital Accumulation and Economic Growth: MacMillan.

Kang, M. P., Mahoney, J. T., \& Tan, D. 2009. Why firms make unilateral investments specific to other firms: The case of OEM suppliers. Strategic Management Journal, 30(2): 117-135.

Kapeferer, J. 1996. Strategic Brand Management. London: Kogan.

Koskinen, K. U., \& Mäkinen, S. 2009. Role of boundary objects in negotiations of project contracts. International Journal of Project Management, 27(1): 31-38.

Kotler, P. 1997. Marketing Management: Analysis, Planning, Implementation and Control. 9th ed. London: Prentice Hall International. 
MacNeil, I. R. 1980. Power, Contract, and the Economic Model. Journal of Economic Issues (pre1986), 14(000004): 909.

Margulies, W. 1977. Make the Most of Your Corporate Identity. Harvard Business Review(JulyAugust): 66-77.

Mason, K., \& Leek, S. 2008. Learning to build a supply network: An exploration of dynamic business models. Journal of Management Studies, 45(4): 774-799.

McLoughlin, D., \& Horan, C. 2002. Markets-as-networks: notes on a unique understanding. Journal of Business Research, 55: 535-543.

Melewar, T. C., \& Saunders, J. 1999. International Corporate Visual Identity: Standardization or Localization? Journal of International Business Studies, 30(3): 583-593.

Meyer, R. E., Höllerer, M. A., Jancsary, D., \& van Leeuwen, T. 2013. The Visual Dimension in Organizing, Organization, and Organization Research: Core Ideas, Current Developments, and Promising Avenues. The Academy of Management Annals, 7(1): 489-555.

Mishra, R., \& Seshadri, S. 2000. Evaluating Relationships in Business Markets: AnEpisoe Level Operationalization, IMP. Bath, UK.

Morgan, R. M., \& Hunt, S. D. 1994. The commitment-trust theory of relationship marketing. Journal of Marketing, 58(3): 20.

Munson, C. L., Rosenblatt, M. J., \& Rosenblatt, X. 1999. The Use and Abuse of Power in Supply Chains. Business-Horizons(January-February): 55-65.

Olins, W. 1991. Corporate Identity. Toledo: Thames and Hudson.

Pilditch, J. 1970. Communication by Design: a Study in Corporate Identity. London: McGraw-Hill.

Reve, T., \& Stern, L. W. 1979. Interorganizational relations in marketing channels. Academy of Management Review, 4(3): 405-416.

Robson, M. J., Leonidou, L. C., \& Katsikeas, C. S. 2002. Factors influencing joint venture performance: theoretical perspectives, assessment and future directions. Managment international Review, 42(4): 385-418.

Seshadri, S., \& Mishra, R. 2004. Relationship marketing and contract theory. Industrial Marketing Management, 33(6): 513-526.

Simões, C., Dibb, S., \& Fisk, R. P. 2005. Managing Corporate Identity: An Internal Perspective. Journal of the Academy of Marketing Science, 33(2): 153-168.

Simoes, C., Dibbs, S., \& Fisk, R. 2005. Managing Corporate Identity: An Internal Perspective. Journal of the Academy of Marketing Science, 33(2): 153-168.

Simões, C., \& Mason, K. 2012. Informing a New Business-to-Business Relationship: the Role of Corporate Identity. European Journal of Marketing, 46(6): 684-711.

Sluss, D. M., \& Ashforth, B. E. 2008. How Relational an Organizational Identification Converge: Processes and Conditions. Organization Science, 19(6): 807-823.

Star, S. L., \& Griesemer, J. R. 1989. Institutional Ecology, 'Translations' and Boundary Objects: Amateurs and Professionals in Berkeley's Museum of Vertebrate Zoology, 1907-39. Social Studies of Science, 19(3): 387-420.

Stogdill, R. M., \& Coons, A. 1957. Leader Behavior: Its Description and Measurement. Columbus: Bureau of Education. Research Monograph, 88(Ohio State University).

Strauss, A., \& Corbin, J. 1998. Basics of Qualitative Research: Techniques and Procedures for Developing Grounded Theory (Second Edition ed.). Thousand Oaks: Sage.

Topalian, A. 1984. Corporate Identity: Beyond The Visual Overstatements. International Journal of Advertising, 3(1): 55-62.

Ulaga, W. 2003. Capturing value creation in business relationships: A customer perspective. Industrial Marketing Management, 32(8): 677-693.

Urban, G. L., Sultan, F., \& Qualls, W. J. 2000. Placing trust at the center of your Internet strategy. MIT Sloan Management Review, 42(1): 39. 
van-Riel, C., \& Balmer, J. 1997. Corporate Identity: the Concept, Its Measurement and Management. European Journal of Marketing, 31(5/6): 340-355.

Varadarajan, P. R., \& Rajaratnam, D. 1986. Symbiotic Marketing Revisited. Journal of Marketing, 50(1): 7.

Zaheer, A., McEvily, B., \& Perrone, V. 1998. Does Trust Matter? Exploring the Effects of Interorganizational and Interpersonal Trust on Performance. Organization Science, 9(2): 141 159. 